\title{
Lehké pivo
}

\section{I. část - Současná situace ve světě}

Ing. MICHAL ČERNŶ, Ing. VLADIMÍR ČERNOHORSKÝ, Ing. JOSEF ŠTICHAUER, Pokusné a vývojové středisko pro pivo a slad, Praha-Braník

Klíčová slova: pivo, lehké pivo, mladina, kvašení, ethanol, extrakt, využitelná energie

\section{Uvod}

$\mathrm{V}$ posledním desetiletí se ve světě rozšríil nový typ piva, tzv. „lehké pivo“. Co vlastně ,lehké p'vo“ je? Toto je otázka, kterou si konzument či nezasvěcený pivovarský odborník položi. Název výrobku zní ponèkud nezvykle, avšak termín ,light beer“ či ,leicht Bier“ je v pivovarské zahran'ční literatuře zcela běžný a charakterizuje určitý typ piva stejně jako ,výčepni“ pivo či ..ležák“. Jaké jsou základní charakteristické rysy lehkého piva? Na tuto otázku nenalezneme však ani v zahraniční literatuře přesnou odpověd, resp. definici. Nejkomplexnější pohled na problematiku lehkých piv podává Brenner [1]. Ani zde není tato otázka jednoznačně zodpovězena. Proto se pokusíme o definici lehkého p'va, která je výsledkem dílčích dostupných informací uváděných v zahraniční literatuře $[1,2,3,4,5,6,7,8,9]$.

"Lehké pivo“" je nový druh piva, který má minimálnĕ o 1/3 snížený. obsah- využitelné energie oproti běžnému $12 \%$ pivu, hluboké prokvašení blížící se prokvašení dosažitelnému a vysoké nasycení $\mathrm{CO}_{2}$.

To jsou společné vlastnosti lehkých piv. uvádẹné v żahraničních pramenech. Rozdíly jsou naopak vôvodní koncentraci, obsahu alkoholu, hořkosti i dalších kritéríich. Důležité je rovněž zjištění, že ani tato definice plně nepostihuje všechny vzorky. Mezi lehká p’va jsou řazena i některá piva $s$ využitelnou energí sníženou pouze o $15-25 \%$ oproti běžným pivûm. Přesto však definice zahrnuje většinu lehkých piv.

\section{Proč vyrábět lehké pivo a komu je urěeno?}

Na otázku je možno nalézt podstatně širší a bohatší odpověd. Vynecháme-li zcela zvláštní podskupinu lehkých piv - nízkoalkoholická piva, u nichž je výroba motivována různými důvody (motorismus, náboženství, sport, zdravotní omezení), pak jsou to především komerční důvody. Trh v pivovarsky vyspělých zemích, kde lze asi $30 \%$ obyvatelstva zařadit mezi pravidelné konzumenty piva, je prakticky nasycen. Lze těžko předpokládat, že by roční spotřeba p'va výrazně stoupla nad současnou vysokou hranici 150 l na osobu. Proto byla nutná inovace výrobku s ohledem na další spotřebitele, které není možno radit mezi tradiční konzumenty piva. Ke komerčním důvodům je nutno $v$ mnoha zemích počítat rovněž otázku spojenou s odvodem daní $\mathrm{z}$ alkoholických nápojů. Ve Švédsku je např. pivo rozděleno do tř̀ skupin podle maximálního povoleného obsahu alkoholu $1,8 \% \mathrm{hm}, 2,8 \% \mathrm{hm}$ a $3,5 \% \mathrm{hm}$. Podle zařazení výrobku do příslušné skupiny se odvádějí daně, takže je 
Tabulka 1. Analytické znaky amerických lehkých piv [1]

\begin{tabular}{|c|c|c|c|c|c|c|c|c|c|c|}
\hline & & 1 & 2 & 3 & 4 & 5 & 6 & 7 & 8 & 9 \\
\hline Extrakt zdánlivý & {$[\% \mathrm{hm}]$} & 1,12 & $-0,44$ & $-0,48$ & $-0,36$ & 0,01 & 0,35 & $-0,36$ & $-0,32$ & 0,03 \\
\hline Alkohol & {$[\% \mathrm{hm}]$} & 2,72 & 3,21 & 3,37 & 3,38 & 2,26 & 2,48 & 3,33 & 3,21 & 3,19 \\
\hline Extrakt skutečný & {$[\% \mathrm{hm}]$} & 2,38 & 1,03 & 1,06 & 1,19 & 1,05 & 1,49 & 1,16 & 1,16 & 1,50 \\
\hline Bilkoviny & {$[\% \mathrm{hm}]$} & 0,32 & 0,28 & 0,20 & 0,23 & 0,33 & 0,11 & 0,26 & 0,25 & 0,16 \\
\hline $\mathrm{pH}$ & & 4,74 & 4,32 & 3,85 & 4,20 & 4,60 & 4,16 & 3,99 & 4,10 & 3,80 \\
\hline Barva & [OSRM] & 2,6 & 2,5 & 1,9 & 3,0 & 4,4 & 2,6 & 2,8 & 2,2 & 2,9 \\
\hline Hořkost & [j. EBC] & 9,0 & 10,0 & 15,0 & 20,0 & 12,0 & 11,0 & 10,5 & 10,0 & 13,5 \\
\hline ITT & [s] & 1800 & 2700 & 1500 & 1800 & 300 & 3600 & 1200 & 1500 & 1500 \\
\hline $\begin{array}{l}\text { Koncentrace mla- } \\
\text { diny }\end{array}$ & [\% hm] & 7,8 & 7,4 & 7,7 & 7,9 & 5,6 & 6,4 & 7,8 & 7,5 & 7,8 \\
\hline $\begin{array}{l}\text { Prokvašení sku- } \\
\text { tečné }\end{array}$ & [\%] & 69,5 & 85,9 & 86,2 & 84,9 & 81,3 & 76,7 & 85,7 & 84,5 & 80,8 \\
\hline $\begin{array}{l}\text { Prokvašení zdán- } \\
\text { livé }\end{array}$ & {$[\%]$} & 85,6 & 105,9 & 106,2 & 104,6 & 99,8 & 94,5 & 104,6 & 104,3 & 99,6 \\
\hline Kalorický obsah & {$[\mathrm{kJ}, 1-1]$} & 1191 & 1108 & 1167 & 1616 & 837 & 979 & 1167 & 1132 & 1191 . \\
\hline
\end{tabular}

zájem výrobců o zařazení do nižší skupiny [26]. Nezajímavá není ani úspora základních surovin, což má za následek pokles výrobních nákladů na lehké pivo, který např. u piva Nürnberger Patrizier činí 8-9 DM za hl [2]. Nutno konstatovat, že v Evropě se tento typ piva př́liš nerozšiřil. Hlavním důvodem je fakt, že pro tradiční konzumenty piva je výrobek ze senzorického hlediska nepř́liš lákavý. Naproti tomu v USA se lehké pivo koncem sedmdesátých let značně rozšiřilo. Jednou z pǐíčin byla i vhodně volená reklama, která způsobila, že lehká piva tvoří v současnosti již $15-20 \%$ celkové produkce piva $v$ USA [2]. $V$ reklamě se zdůrazňují především zdravotní důvody - tj. snaha o vyrobení tzv. „zdravějšího piva“, které má nižší využitelnou energii.

\section{Co Činí lehké pivo lehkým?}

- Na tuto otázku je možno odpovědět po zjištění celkové využitelné energie piva. Ta se vypočte podle známého vztahu, který uvádí Klazar [15].

kde $e_{\mathrm{n}}$

$$
e_{\mathrm{n}}=\{n \times 3,8+a \times 7,1) \times 4,1868
$$

je využitelná energie [kJ].100 $\mathrm{g}^{-1}$ ],

$n$ - skutečný extrakt piva [\% hm]

a - obsah alkoholu v pivu $[\% \mathrm{hm}]$,

4,1868 - přepočet kcal na [kJ].

Helbert [11] uvádí poněkud odlišný způsob výpočtu:

$$
\left.e_{\mathrm{n}}=(n-0,15) \times 4,0+a \times 6,9\right) \times 4,1868
$$

kde symboly jsou stejné jako u předešlé rovnice a 0,15 průměrný obsah popela v sušině.

Celková využitelná energie běžných $12 \%$ piv se pohybuje v rozmezí $1650-1900 \mathrm{~kJ} . \mathrm{l}^{-1}, 10 \%$ piv $1450-1650$ $\mathrm{kJ} \cdot \mathrm{1}^{-1}$.

Z uvedených dat je zřejmé, že lehká piva maji širší rozmezí obsahu využitelné energie. Tento poněkud velký rozptyl $\mathrm{v}$ jednom ze základních znaků lehkého piva je zpûsoben velkými rozdíly technologie, a zejména rozdíly původní koncentrace mladiny. Pro ilustraci o základních analytických znacích lehkých piv uvádíme 2 tabulky. Z nich vyplývá, že některé vzorky mají využitelnou energii dokonce vyšší než $1300 \mathrm{~kJ} \cdot \mathrm{l}^{-1}$ a přesto jsou zařazeny do této skupiny piv. Dále je zřejmé, že v nejrozšŕřenějšś skupině lehkých piv se původní koncentrace mladiny pohybuje okolo $7,5 \%$ hm. Piva mají malý rozdíl zdánlivého a dosažitelného prokvašení a mnohá se blíží charakteru dia piv. Pro větší názornost vyjímáme

\begin{tabular}{|c|c|c|}
\hline Relativní hustota & 0,99 & 1,00923 \\
\hline Zdánlivý extrakt & 0,48 & $2,37 \% \mathrm{hm}$ \\
\hline Alkohol & 2,26 & $3,37 \% \mathrm{hm}$ \\
\hline Skutečný extrakt & 1,05 & $3,87 \% \mathrm{hm}$ \\
\hline $\mathrm{pH}$ & 3,80 & 4,74 \\
\hline Hořkost & 9,0 & $-20,0$ i EBC \\
\hline Zdánlivý stupeñ prokvašení & 85,6 & $-108,2 \%$ \\
\hline Obsah bilkovin $[\mathrm{N} \times 6,25]$ & 0,11 & $-\quad 0,33 \% \mathrm{hm}$ \\
\hline Využitelná energie & 837 & $-1629 \mathrm{~kJ} \cdot \mathrm{l}^{-1}$ \\
\hline
\end{tabular}
souhrn nejdůležitějších analytických hodnot [1].
Brenner [1] rozděluje lehká piva podle obsahú využitelné energie do tři skupin. První nejrozšiřenější skupinu tvoří piva, která mají o jednu třetinu nižší energetický obsah než běžná standardní piva.

Výrobky druhé skupiny mají asi o polovinu nižší využitelnou energii oproti běžným pivům a nejsou tak rozšířeny. Patří sem např. Miller Players, Olympia Gold.

Do třetí skupiny je možno řadit piva, která mají o 15 až $25 \%$ nižší využitelnou energii než běžná piva $z$ toho kterého pivovaru. Patří sem Michelob Light, Coors Light, a Stroh Light. Brenner [1] je zařazuje rovněž mezi lehká piva. Pro ilustraci uvádíme přehled největších výrobců lehkého piva v USA [1]: "Müller Lite $55 \%$, Anheuser Busch $17 \%$, Schlitz Light $12 \%$, Olympia Gold $4 \%$, ostatni $12 \%$.

$\mathrm{Z}$ dalších významných světových výrobců lehkých piv je možno jmenovat $[12,13]$ : Kirin - (Japonsko), Molson, Iabatt - (Kanada), Faxe (Dánsko), Schwechater Krone - (Rakousko), Tree Towns [Švédsko], Kindl Bräu Extra - (NDR), Nürnberger Patrizer - (NSR).

Zajímavé je rovněž připomenout rozdíly v ceně výrobku, které jsou asi o jednu třetinu nižší než cena běž ných piv [12], avšak jsou i mírně vyšší než ležáky [14]

Tabulka 2. Základní analytické znaky lehkých piv růz-

\begin{tabular}{|c|c|c|c|c|}
\hline Vzorek & $\begin{array}{l}\text { Pûvodni } \\
\text { koncen- } \\
\text { trace } \\
{[\% \mathrm{hm}]}\end{array}$ & $\begin{array}{l}\text { Alkohol } \\
{[\% \text { hm }]}\end{array}$ & $\begin{array}{c}\text { Skuteč- } \\
\text { ný } \\
\text { extrakt } \\
{[\% \text { hm }]}\end{array}$ & $\begin{array}{l}\text { Využitelná } \\
\text { energie } \\
[\mathbf{k}] \cdot 1-1]\end{array}$ \\
\hline $\begin{array}{l}\text { USA: Miller Lite } \\
\text { AB Natural Light } \\
\text { AB Michelob Light } \\
\text { Schlitz Light } \\
\text { Coors Light } \\
\text { Strohs Light } \\
\text { Gablingers }\end{array}$ & $\begin{array}{r}7,8 \\
7,8 \\
10,4 \\
7,7 \\
8,7 \\
9,2 \\
8,1\end{array}$ & $\begin{array}{l}3,3 \\
2,9 \\
3,3 \\
3,2 \\
3,5 \\
3,5 \\
3,5\end{array}$ & $\begin{array}{l}1,2 \\
2,0 \\
3,9 \\
1,4 \\
1,7 \\
2,3 \\
1,0\end{array}$ & $\begin{array}{l}1168 \\
1185 \\
1620 \\
1172 \\
1302 \\
1411 \\
1193\end{array}$ \\
\hline $\begin{array}{l}\text { Kanada: Molson Light } \\
\text { Latatts Lite }\end{array}$ & $\begin{array}{l}9,7 \\
8,1\end{array}$ & $\begin{array}{l}3,5 \\
3,3\end{array}$ & $\begin{array}{l}2,9 \\
1,6\end{array}$ & $\begin{array}{l}1093 \\
1235\end{array}$ \\
\hline $\begin{array}{l}\text { Anglie: Hemeling Lite } \\
\text { A:ctic Lite } \\
\text { Low C Pale Ale } \\
\text { Heineken Lager } \\
\text { Skol Lager }\end{array}$ & $\begin{array}{l}8,0 \\
8,4 \\
7,8 \\
8,5 \\
9,4\end{array}$ & $\begin{array}{l}3,3 \\
3,5 \\
3,2 \\
2,8 \\
3,0\end{array}$ & $\begin{array}{l}1,3 \\
1,5 \\
1,3 \\
2,8 \\
3,3\end{array}$ & $\begin{array}{l}1185 \\
1277 \\
1155 \\
1289 \\
1432\end{array}$ \\
\hline Dánsko: Calorius & 8,5 & 3,7 & 1,2 & 1285 \\
\hline Libanon: Almaza & 9,7 & 2,9 & 3,9 & 1503 \\
\hline $\begin{array}{l}\text { Nový Zéland: Lion } \\
\text { Hilo } \\
\text { Leopard }\end{array}$ & $\begin{array}{l}9,4 \\
9,1 \\
9,3\end{array}$ & $\begin{array}{l}2,9 \\
3,7 \\
2,9\end{array}$ & $\begin{array}{l}3,5 \\
1,8 \\
3,5\end{array}$ & $\begin{array}{l}1436 \\
1386 \\
1436\end{array}$ \\
\hline $\begin{array}{l}\text { Jižni Afrika: Culemborg Lite } \\
\text {,P“ }\end{array}$ & $\begin{array}{l}8,0 \\
9,5\end{array}$ & $\begin{array}{l}3,0 \\
3,5\end{array}$ & $\begin{array}{l}1,9 \\
2,5\end{array}$ & $\begin{array}{l}1197 \\
1444\end{array}$ \\
\hline $\begin{array}{l}\text { Keña: Tusker } \\
\text { White Cap }\end{array}$ & $\begin{array}{l}9,4 \\
9,6\end{array}$ & $\begin{array}{l}2,9 \\
3,2\end{array}$ & $\begin{array}{l}3,6 \\
3,3\end{array}$ & $\begin{array}{l}1453 \\
1490\end{array}$ \\
\hline Maroko: Gigigne & 9,1 & 3,0 & 3,1 & 1398 \\
\hline
\end{tabular}
ných výrobců [3] 
Cena výrobku je však závislá na mnoha faktorech, a proto není možno tento údaj brát jako srovnatelný pro tvorbu cen lehkého piva v ČSSR.

\section{Jak se lehké pivo vyrábí?}

Ze základního vztahu pro výpočet využitelné energie piva vyplývá, že lehké pivo je možno vyrobit bử snižením obsahu alkoholu či snížením skutečného extraktu piva, nebo kombinací obou metod.

Jako nejjednodušší se nabízí pouhé snížení koncentrace původní mladiny. Snižení koncentrace je sice základní podmínkou, avšak z dlouhodobé zkušenosti vyplývá, že tato nejjednodušší cesta vede pouze k výrobě tzv. konzumních piv. Odbyt těchto piv v pivovarsky vyspělých zemích stále klesá. Proto se technologie lehkých piv od klasické odlišuje a většinou je i patentově chránĕna.

Výrazným snížením obsahu alkoholu v pivu je možno získat tzv. nízkoalkoholická, resp. nealkoholická piva, která tvoří zvláštní podskup'nu lehkých piv. Problematika jejich výroby je široce publikována $[16,17,18,19$, $20,21,22,23,24,25]$. Základním rysem těchto výrobkû však je, že v menší či větší míre mění senzorický charakter piva. Spotřebitel je proto pije většinou pouze za situace, kdy z jakýchkoli důvodů nemůže konzumovat normální pivo. Proto není ani do budoucna předpoklad, že by se toto pivo stalo vážným konkurentẹm běžných druhů piv.

Další možností, jak mírně snižovat obsah alkoholu, je snížení dosažitelného prokvašení piva za současného snížení koncentrace mladiny. Tento princip se využívá zejména $\mathrm{v}$ zemích, kde je stanovena hranice obsahu alkoholu pro odvod daní $\mathrm{z}$ alkoholických nápojů (napĩ. Švédsko 2,8 \% hm). Dosahuje se toho změnou sypání a potlačením nižší cukrotvorné teploty tak, aby dosažitelný stupeň prokvašení byl co nejnižší. Z piv, která jsou vyrobena touto technologií, je možno jmenovat Tree Towns (Švédsko), Patritia (NSR) a Kindl Brảu Extra (NDR). Stejným principem se řídí technologie výroby $8 \%$ piva Budvar pro export do Švédska.

Technologie výroby většiny lehkých p v zejména v USA je však - jak z předešlých analytických údajů vyplývá - založena na snižování skutečného extraktu, čehož se dosahuje hlubokým prokvašením. Základní principy výroby lze rozdělit do 4 bodů [1]:

1. zředění normálního piva vyšší koncentrace,

2. použití amylolytických enzymů,

3. použití cukru jako surogátu,

4. použití sladových enzymů ze speciálních sladů.

1. Takto se získá nevyrovnaný výrobek, který má naprosto jiný senzorický charakter (hořkost, podíl extraktu ze sladu atd.).

Proto se tento princip většinou nepoužívá.

2. Používají se enzymy amyloglukosidasy, štěpící vazby 1,4 a 1,6-oligosacharidů až na glukosu, která je zkvašována. Přidávají se většinou za studena v průběhu hlavního kvašení. Nevýhodou je, že amyloglukosidasa je při pasteraci oslabována, nikoliv však zničena. To přináší problémy zejména pro možnost částečného smišení s běžným pivem (protláčky). Piva pak vykazují rychle výrazné zesládnutí. Negativní je rovněž dopad na kvalitu pěny. U lehkých piv a zejména diabetických piv tato změna není tak výrazná, vzhledem k nízkému obsahu zbytkových zatěžujících sacharidů.

Přesto je tato technologie značně rozšírena pro svou jednoduchost a dobrý výsledný senzorický charakter piva. V poslední době byly vyvinuty enzymy, které jsou při pasteraci zcela zničeny, tzv. Fungal- $\alpha$-amylasy, které navíc nemají negativní dopad na kvalitu pěny.

3. Přídavek cukru (většinou ve formě sirupu), který je stoprocentně zkvasitelný, je velmi účinný a běžně se používá. Dosáhne se tak výrazného zvýšení dosažitelného prokvašení a aplikuje se většinou ve varně. Naopak negativně působí na trvanlivost pěny.

4. Použití diastatického sladu spolu s využitím zcukřovací teploty 60 a $65^{\circ} \mathrm{C}$ dává vysoce zkvasitelnou mladinu. Avšak nebylo by realistické očekávat skutečný stupeň prokvašení nad $68-70 \%$ (zdánlivé prokvašení 84 až $86 \%$ ), jako výsledek tohoto procesu. Na druhé stranĕ je možno použít např. sterilované sladové moučky vyro- bené $\mathrm{z}$ vysoce diastatického sladu. Tyto prídavky se aplikují do kvasného tanku stejným způsobem jako amylolytické enzymy; takže je možno dosáhnout skutečného prokvašení $75-80 \%$, ne však vyšší (jako amyloglukosidasa), nebot slad má nízkou aktivitu limitní dextrinasy.

Kromě těchto základních technologických principů výroby lehkého piva se používá pochopitelně i kombinace jednotlivých metod. Je to např. částečné snižení obsahu alkoholu z běžných druhů piva na spec'álních zařizeních (reverzní osmóza, vakuová destilace, odpar v tenké vrstvě atd.], používaných většinou pro výrobu bezalkoholových piv. Problémem však jsou vysoké pořizovací náklady těchto zařízení.

\section{Porovnání lehkého piva „ěeského typu“ se zahraniĕními vzorky}

Při analytickém a senzorickém porovnání bylo celkem posouzeno 10 vzorků zahraničních lehkých piv a 2 vzorky čs. piv se sníženým obsahem využitelné energie. Analytické rozbory i senzorịcké hodnocení se prováděly v PVS Braník v různém časovém období.

Některé vzorky posuzovala rovněž oborová degustační komise pr̃i GR̆ PaS.

Výsledky chemické analýzy zahraničních vzorků lehkých piv v porovnání s čs. pivy jsou uvedeny v tabulce 3 .

Vzhledem k rozdílnému množství lahví jednotlivých vzorků je i rozdílný počet analýz, které tak nemohly být provedeny ve stejném rozsahu u všech piv.

\section{Z tabulky 3 vyplývá:}

- Vzorky LITE I a II, Natural Light, ARROIS Light a COORS Light I, maji charakter dia piv a byly vyrobeny zr̃ejmě aplikací dodaných amylolytických enzymú. Svědčí o tom hluboké dosažitelné prokvašeni těchto

- Zajimavý je rozdil mezi pivem coors Light I a II. Vzhledem k tomu, że mezi posouzením těchto vzorkú je rozdíl téméř 3 let, je pravděpodobné, że v prúběhu doby se mohla změnit výrobní technologie, kdy se upustilo od príidavku amylolytických enzymú. - odlišný charakter měly vzorky THREE TOWNS, Kindı Bräu Ext:a, a $8 \%$ Budvar, které měly dosacitelné prokvašení nízké zdánliveho prokvašen. \{max, 3,6 \%)

- Ostatní vzorky - tj. COORS Light II, BUD Light, Stroh Light mẽly dosa itelné prokvašen. mezi $79,3-89,8 \%$, tj. obdobné lehké. mu pivu českého typu pr̃ipravovanému v PVS Braník.

- Obsah alkoholu amerických lehkých piv, s vý imkou piva BUD Light, nevyhovoval požadavkûm na obsah alkoholu pod hranicí $2,8 \% \mathrm{hm}$, která e rozhodujíc pro zar̂azen do kategorie lehkých p v v některých západoevropských zemích. Hran ci ob ahu alkoholu $2,8 \% \mathrm{hm}$ spln ly naopak evropské vzorky. U vzorku ARTOIS L.ght byla tato podm nka splněna za cenu snížení koncentrace mladiny na $6,5 \% \mathrm{hm}$.

- Koncentrace pûvodní mladiny většiny vzorků byla asi $8 \% \mathrm{hm}$, avšak v souladu s literárními údaji jou i zde odlišnosti. (Artois Light, Kindl Bräu Extra (NDR), Stroh Light).

- Vyużitelná energie vẽtš̃iny vzorkú byla nižší než $1300 \mathrm{~kJ} .1-1$ - V hořkosti byly značné rozdíly, avšak s výjimkou Kindl Bräu Extra byla hořkost výrazně nižší ve srovnání s ,lehkým pivem ceského typu", připraveným v PVS Braník.

- Obsah polýenolú značně kolísal [od $78,7-148,4 \mathrm{mg} \cdot 1-1$ ] v dũ sledku rozdilné technologie výroby, rũzné stabilizace i stárí vzorku.

- Obsah $\mathrm{O}_{2}$ byl u všech vzorkú velmi nízký.

- Trvanlivost piv nemohla být komplexnè vyhodnocena, nebot nebyly podklady o době stočení piv.

\section{Výsledky senzorické zkoušky}

- Vzorky mẽly velmi rozdílnou senzorickou kvalitu, od velm dobré po nevyhovující. Vliv na tyto rozdíly má pochopitelně i stárí piva.

- Hlavním nedostatkem u některých piv byla esterová, kvasničná až zatuchlá cizi vúně a natrpklá a kvasničná cizí chut (Stroh Light, Artois Light, Tree Towns).

- Všechna piva měla velmi dobrý říz a pěnivost zpûsobenou vysokým nasycením $\mathrm{CO}_{2}$.

- Hořkost všech zahraničnich piv byla v prũmăru slabší, nejvýše str̃̌ední intenzity, převážně jemného charakteru, což dokumentuje nízké chmelení.

- U všech vzorkủ byla konstatována až přilišná prázdnost chuti slabá plnost, vyplývající z hlubokého prokvašení.

$\mathrm{V}$ posouzení celkového subjektivního dojmu pr̃i anonymnim předložení vzorkú byl nejlépe hodnocen vzorek lehkého piva „ट̌eského typu" pr̃ipravený $\mathrm{v}$ PVS Braník.

Souhrnně lze konstatovat, že lehké pivo tzv. „českého typu“ je plně srovnatelné s obdobnými výrobky předních zahraničních výrobců a v anonymním senzorickém hodnocení bylo oborovou degustační komisí označeno jako nejlepší.

\section{Prosadí se lehké pivo na trhu v ČSSR?}

Toto je zatím velmi obtížná otázka. Pracovníci PVS Braník řešili vývoj hluboce prokvašeného piva - tzv. 
Tabulka 3. Chemický rozbor piva

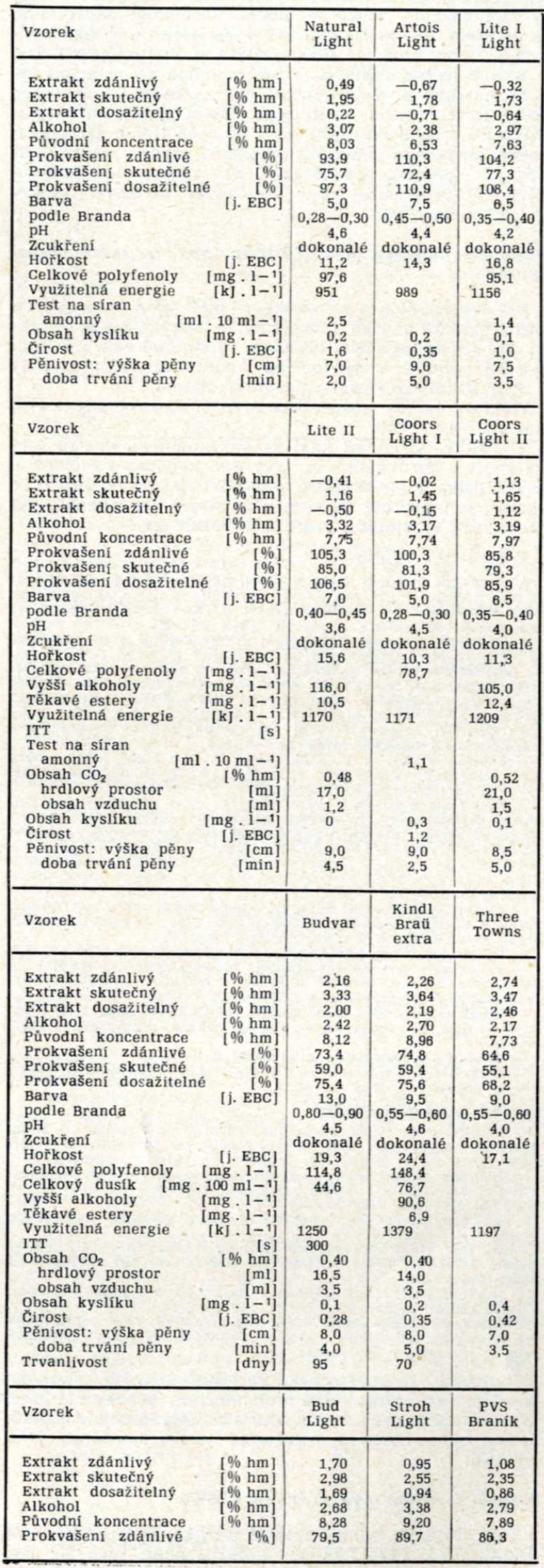

Pokračování tabulky 3

\begin{tabular}{|c|c|c|c|}
\hline Prokvašení skutečné & 64,0 & 72,3 & 70,2 \\
\hline Prokvašeni dosažitelné [\%] & 79,6 & 89,8 & 89,1 \\
\hline Barva & 6,0 & 8,5 & 8,0 \\
\hline $\begin{array}{l}\text { podle Branda } \\
\mathrm{pH}\end{array}$ & $0,35-0,40$ & $0,50-0,55$ & $0,45-0,50$ \\
\hline Zcukr̃eni & dokonalé & dokonalé & $\begin{array}{c}4,5 \\
\text { dokonalé }\end{array}$ \\
\hline Hořkost & 13,0 & 9,2 & 23,0 \\
\hline Celkové polyfenoly [mg. $1-1]$ & & & 90,2 \\
\hline Celkový dusík [mg. $100 \mathrm{ml}-1]$ & & & 35,8 \\
\hline Vyšší alkoholy [mg . 1-1] & 81,0 & 128,0 & 52,5 \\
\hline Tĕkavé estery & 12,4 & 14,2 & 8,8 \\
\hline Využitelná energie & 126,9 & 140,8 & 121,0 \\
\hline $\begin{array}{l}\text { ITT } \\
\text { Test na síran }\end{array}$ & & & 0 \\
\hline amonný $\quad\left[\mathrm{ml} \cdot 10 \mathrm{ml}-^{-1}\right]$ & & & 2,2 \\
\hline $\begin{array}{r}\text { Titrační kyselost [mi NaOH }(\mathrm{C}= \\
\left.=\mathrm{mol}^{-1} \cdot 1-100-1\right]\end{array}$ & & & $\begin{array}{l}2,6 \\
0,47\end{array}$ \\
\hline Obsah $\mathrm{CO}_{2} \quad[\% \mathrm{hm}]$ & 0,49 & 0,51 & 14,3 \\
\hline hrdlový prostor & 21,0 & 21,0 & 5,9 \\
\hline obsah vzduchu & 1,0 & 2,1 & 0,20 \\
\hline Obsah kyslíku & 0 & 0,1 & 0,20 \\
\hline Čirost $\quad[\mathrm{j} . \mathrm{EBC}]$ & & & 0,20 \\
\hline $\begin{array}{l}\text { Pěnivost: výška pěny } \\
\text { doba trváni pěny }\end{array}$ & $\begin{array}{l}9,5 \\
5,0\end{array}$ & $\begin{array}{l}9,5 \\
5,0\end{array}$ & 8,0 \\
\hline doba trvání pěny & 5,0 & 5,0 & 7,0 \\
\hline
\end{tabular}

„lehkého piva“ v rámci úkolu RVT v roce 1984. Výsledkem práce je nový druh piva, jehož výroba byla úspěšně ověřena v pivovaru Gambrinus. Avšak již v počátku vývoje byly řešitelủm zřejmé obtíže se zavedením piva na čs. trh. V Československu má výroba piva bohaté tradice a nelze očekávat, že by tento výrobek mohl konkurovat běžným druhům piv. Připočteme-li $\mathrm{k}$ tomu řadu závažných problémů (zejména přetíženost vý̛robních kapacit), které musí pivovary řešit, je zavedení lehkého piva na čs. trh velmi problematické. Jako reálná přichází v úvahu varianta výrobku v exkluzívním balení, prvotřídní jakosti s dlouhodobou trvanlivostí, která by pomohla obchodním organizacím zajistit formou předzásobení ve velkoobchodních skladech plynulé dodávky piva obyvatelstvu i v odbytových špičkách. Podstatná je rovněž otázka maloobchodní ceny, nebot ta může $\mathrm{v}$ rozhodující míře ovlivnit koupěschopnost lehkého piva.

Vývoj lehkého piva tzv. „českého typu“ byl v PVS Braník úspěšně ukončen. 0 jeho výsledcích $\mathrm{i}$ jejich praktické aplikaci při výrobě běžných druhů piv bude podrobněji pojednávat II. část článku.

\section{Literatura}

[1] BRENNER, M.: Brauwelt 119, 1979, č. 3, s. $42-45$

[2] Brauwelt, 120, 1980, č. 1/2, s. 8-16

[3] PIENDL, A.: Brauwelt, 120, 1980, č. 30, s. 1131

[4] Brauwelt, 119, 1979, č. 45, s. 1614

[5] Brew. and Distill. Inter., 1979, č. 11, s. 20-21 -ref. Brauwissenschaft, 1980, č. 5, s. 130

[6] WERRES, R.: Getränke-Revue, 1979, č. 10, s. 30 ref. Brauwiss, 1981 , č. 1, s. 28

[7] Food Engng. int. 3, 1978, č. 12, s. $27-30,32$

[8] Brauwelt, 117, 1977, č. 14, s. 417

[9] Brauwelt, 116, 1976, č. 18, s. 537

[10] ČSN 560186 z 1 . 7. 1983

[11] HELBERT: ASBC 36, s. $66-68,1978$

[12] Brauwelt, 122, 1982, č. 11, s. 449

[13] Brauwelt, 122, 1982, č. 15 , s. 615

[14] Brauwelt, 116, 1976, č. 18 , s. 537

[15] KLAZAR, G.: Možnost výroby dietních, diabetických a nízko. alkoholických piv. Závěrečná práce PVŚ Braník 1973 [16] KLAZAR, G., CUR̃in, J.: Výroba nízkoalkoholického piva. Zá-

[17]GRUNENBERG: Brauwelt, 122, 1982, č. 50, s. $1669-70$

[18] NIELSEN, C. Eđ.: Brew. and Distill int. 12, 1982, č. 8, s. 39-41

[19] KIENINGER, H.: Brauwelt, 121, 1981, č. 17, s. 574-581

[20] NiEfiND, H. J.: Brauwelt, 121, 1981, č. 26 , s. $964-5$

[21] Brauwiss., 34, 1981, č. 7, s. 171-2

[22] Brauwiss., 31, 1978, č. 6, s, 167

[23] Brauerei J., 30, 1977 , č. 16, s. $444-450$

[24] Brauwiss., 29, 1976, č. 3, s. 76

[25] SCHMiTZ, F. J.: Mschr, Brauerei, 35, 1982, č. 3, s. 92-94

[26] HƯBNER: přednáška fy Alfa-Laval, Pivovarsko-sladařské dny Brno 83

[27] VANČURA et al.: Pivovarsko-sladařská analytika, SNTL 1966

[28] MOŠTEK J.: Analytické metody ke cvičení z kvasné chemie a technologie SNTL, 1973

[29] ENARI, T. M.: Analytica EBC - Zurich 1975 
[30] BASAR̆OVÁ, G., ČERNĀ, I.: Kvas. prũm., 21, 1975, s. 217

[311] CUR̆ín, J.: Kvas. prûm., 16, 1970, č. 7/8, s. $156-160$

[32] SCHUSTER, K., RAAB, H.: Brauwiss, 1961, č. 14 , s. 246

[33] HARTONG, B. D.: 70 F. Br. 1925, č. 46, 543

Černý M. - Černohorský V. - Štichauer J.: Lehké pivo I. - Současná situace ve světě. Kvas. prûm., 32, 1986, č. 10 , s. $227-231$.

Autoři přinášejí přehled poznatků o novém druhu piv se sníženou využitelnou energií o tzv. "lehkém pivu“. Tento termín je $\mathbf{v}$ zahraniční literatuře zcela běžný. Lehká piva se rozšiřila zejména na trhu v USA, kde jejich výroba činí $15-20 \%$ z celkové produkce. V Evropě se tento druh piva příiš nerozšiřil, nebot se $v$ menší či větší míre odlišuje svými senzorickými vlastnostmi od běžných druhů piv.

Přesto, že ani v zahraniční literatuře není možno nalézt přesnou definici termínu ,lehké pivo“, autoři se ze souhrmu informací pokoušejí tento typ piv definovat. Uvádějí se důvody pro zavedení lehkého piva na trh, rozdělení do různých skupin podle použité výrobní technologie i obsahu využitelné energie včetně nejznámějších světových výrobků a základního rozboru těchto piv. V závěru jsou uvedeny výsledky analytického i senzorického porovnání některých zahraničních druhů lehkých piv s pivem vyvinutým v Pokusném a vývojovém středisku pro pivo a slad, Praha-Braník (PVS).

V ČSSR se problematikou výroby lehkého piva tzv. „českého typu“ zabývali pracovníci PVS Braník v roce 1984. V druhé části článku, která bude uveřejněna rovněž v Kvasném průmyslu, chtějí autoři čtenáře seznám't s výsledky své práce i s aplikací dílčích poznatků do běžné praxe pivovarských technologů.

Черны, М. - Черногорски. В. - Штихауер, И.: Легкое пиво 1. Современное состояние в мире. Квас. прум. 32, 1986, № 10, стр. 227-231

Авторы дают краткий обзор сведений о новом сорте пив с пониженной используемой энергией, т. наз. »лег ком пивеж. Этот термин в зарубежной литературе весьма часто употребляется. Легкие пива распространились особенно с США, где их продукция составляет $15-20 \%$ суммарной продукции. В Европе этот сорт не слишком широко производится, потому что он по меньшей или большей мере отличается по свонм вкусовым свойствам от обычных сортов пив.

Несмотря на это, и в зарубежной литературе трудно подыскать точное определение этого типа пива, авторы пытаются дать на основе имеющихся сведений определение »легкого пиваж. Приводятся также доводы для введения легкого пива на рынок, разделенные в разные группы по примененной технологии производства и содержанию используемой энергии включая наиболее известные товары в мире и основной анализ этих пив. В заключение приводятся результаты аналитического и смыслового сравнения некоторых заграничных сортов легких пив с пивом, разработанным в Центре для испытания и разработки пива и солода, Прага-Браник (ПВС). В ЧССР проблематикой производства легкого пива т. наз. »чешского типа« занимались сотрудники ПВС Браник в 1984 г.

Во второй части статьи, которая будет также опубликована в этом журнале, авторы хотят познакомить читателя с результатами своей работы и приложением частных результатов в производственной практике технологов пивоварения.
Černý, M. - Černohorský, v. - Štichauer, J.: Light Beer I - Present Situation in the World. Kvas. prum. 32, 1986, No. 10 , pp. $227-231$.

Authors discuss knowledges about the new type of beer with a lowered utilizable energy that is called "light beer". This term is quite usual in the foreign literature. The light beers are mainly spread in the U.S.A. where their production is 15 to $20 \%$ from the whole production. In Europe this type of beer has not been so spread since its sensoric properties are more or less different from the usual types of beer. From the gathering of information the authors try to define this type of beer despite of no correct definition of the term "light beer" exists in the foreign literature yet. The reasons for a sale of light beer are described. These beers are divided into different groups according to the production technology, the quantity of utilizable energy and the basic analyses of beers. At the end the analytical and sensoric results of some foreign types of light beer are compared with beer that was developed in Experimental and Development Center for Beer and Malt, Prague-Braník. The development of a light beer production of so called "Czech Type " was made in this center in 1984. In the second part of the article, that will also be published in this journal, the authors want to inform about their results including the application of several knowledges into the usual practice of brewing technologists.

Černý, M. - Černohorský, v. - Štichauer, J.: Leichtbier I. Der gegenwärtige Stand in der Welt. Kvas. prům. 32, 1986, Nr. 10, S. 227-231.

Die Autoren bringen eine Übersicht der Erkenntnisse und Erfahrungen mit dem sog. Leichtbier - neuer Biersorte mit verringerter ausnützbarer Energie. Diese Bezeichnung ist in der Weltliteratur geläufig. Das Light Beer hat sich vor allem in den USA durchgesetzt, wo sein AusstoB 15-20\% der Gesamtproduktion ausmacht. In Europa ist seine Verbreitung bisher sehr gering, was durch die Unterschiede seiner sensorischen Eigenschaften von den der traditionellen europäischen Biersorten erklärbar ist.

Obwohl in der ausländischen Literatur keine präzise Definition der Bezeichnung ,Leichtbier" zu finden ist, versuchen die Autoren aufgrund einer umfangreichen Informationsrecherche diesen B ertyp zu charakterisieren und definieren. Es werden die Gründe für die Einführung dieses Biertyps auf den Markt angeführt, die Aufteilung auf verschiedene Erzeugnisgruppen nach der angewandten Technologie und nach dem Gehalt der ausnützbaren Energie erörtert, renommierte Leichtbiermarken durch ihre Analysenwerte charakterisiert. Zum Schluß werden die Ergebnisse des analytischen und sensorischen Vergleichs einiger ausländischer Leichtbiere mit dem Bier angeführt, das in dem Versuchs- und Entwicklungszentrum der Brauindustrie in Prag-Braník entwickelt wurde. In der ČSSR befaßt sich das erwähnte Versuchszentrum mit der Problematik der Entwicklung eines Leichtbiers vom „böhmischen“ Typ
seit 1984 .

In dem 2. Teil des Artikels, der in derselben Fachzeitschrift anknüpfend veröffentlicht wird, werden die Autoren über die Ergebnisse ihrer Versuchsarbe ten berichten und die Applikationsmöglichkeiten in der technologischen Betriebspraxis erörtern. 